\title{
Poetry in Action: \\ From the Gift Economy to Corporate Philanthropists ${ }^{1}$
}

\author{
By Lorenzo Gelmini
}

\begin{abstract}
The role of patronage has been widely examined in studies in different disciplines, from the arts to sociology. This paper adopts a novel interdisciplinary approach to investigate the relationship between patronage, corporate philanthropy, and the economic (and non-economic) returns for donors. In an ancient Latin literature perspective, the case study analyzes the literary works of Horace, master poet and noteworthy exemplum of cursus honorum and Latin patronage. Highlighting some pivotal poetic lines (from a managerial standpoint), the study proposes a patronage and gift economy framework as the building blocks for corporate philanthropy and corporate social responsibility actions. While patronage fosters the development of economic relationships, even if in a nonlinear and multi-faceted way, corporate philanthropy promotes relationships aimed at achieving positive returns for the donor, be they economic or metaeconomic, instantaneous or delayed. Although more difficult to capture through the usual cash inflow and outflow measurements, corporate philanthropy and corporate social responsibility express an elusive but valuable economic relationship. Therefore, this study offers some managerial insights for nonprofit corporations and those industries - for example, sports - where the economic returns may not be a central element of the investment. Finally, it is noteworthy that Horace is, among other things, an author of great modernity for his tension, articulated and complex, towards the active events of his time. His rediscovery, not only in literary studies, has allowed to add to other disciplines the analysis of an intellectual, divided between art and current life.
\end{abstract}

Keywords: Latin literature, patronage, corporate philanthropy, gift economy, non-financial performance

\section{Introduction}

The role of patronage has been widely explored in different disciplines, from the arts to sociology. We adopt a novel interdisciplinary approach and an ancient Latin literature perspective (particularly the Golden Age of Augustus, Maecenas, and Horace) to investigate the relationship between patronage, corporate philanthropy, and the economic (and non-economic) returns for donors. This is an elusive but valuable relationship with considerable implications for entrepreneurship, from not-for-profit organizations to sports management.

\footnotetext{
*Assistant Professor, University of Eastern Piedmont, Italy.

${ }^{1}$ The paper is the third, out of four, installment of a project regarding arts, in particular Latin Poetry, patronage and corporate philanthropy.
} 
The paper is structured as follows. The next section describes the main contributions in the literature, briefly illustrates Horace's life and the role of patronage in the arts in the Golden Age in Rome. We then develop our case study and propose a patronage and gift economy framework, offering suggestions and insights for a corporate philanthropy. The final section provides the conclusion, limitations, and future research avenues.

\section{Literature Review}

Classicists and sociologists define patronage as an asymmetrical personal relationship of some duration that involves the reciprocal exchange of goods and services (Saller 1982). From the patron's side, the advantages of the exchange might be political or not, for instance, enhancing man's auctoritas and dignitas, offering both economic and non-economic returns. Corporate philanthropy, on the contrary, is the assemblage of corporate (a public entity organized around a central theme driven by an economic, legal, and social purpose) and philanthropy (that is, love of fellow man). In general, "corporate philanthropy describes the role and responsibility of the firm to recognize its societal obligation and to execute initiatives to benefit its constituents - altruistic capitalism" (Fioravante 2010). In this sense, patronage and corporate philanthropy share some elements: both entail a gift relationship, a "non-commercial social transfer of wealth, material objects or non-material assistance rendered in forms that are culturally meaningful and that generate moral relationship between individuals or groups such as solidarity, dependence, legitimacy, and reputability" (Kidd 1996).

At the same time, scholars point out some differences between individual patronage and different forms of foundations or corporations. "In recent decades patronage has taken an interesting turn away from the individual and personal form in which it appeared for so long and has become strangely depersonalized and institutionalized" (Gold 2012), and in so doing, "recipients are not expected to laud the virtues of the sources of their income" (Gold 2012).

Patronage in the arts has a long history. While the nature and extent of the influence of literary patronage has been debated, "patronage itself has endured for as long as literature" (Gold 2012). Dating back to ancient Greece, it was chiefly associated with autocratic rulers (although in Athens, the choregia was a kind of democratization of the patronage principle), but also played a significant role in ancient Rome. In this sense, in the Golden Age, "Augustus and Maecenas gathered round them the greatest intellectual figures of the period and gave them both economic support and cultural stimulus. Maecenas especially, in his role as both close ally of Augustus and amateur of new poetry, gave to Virgil, Horace, Propertius, and others personal friendship and generous financial support" (Oxford Dictionary, retrieved August 2019) ${ }^{2}$.

\footnotetext{
${ }^{2}$ The Golden Age is commonly identified as the time of benefactions of empire in Augustan literature.
} 
Worth noting is that the word philanthropia originally referred to the relationship of the gods with humans, encapsulating the notion of return (philanthropon) from the recipients in the form of honors heaped on the donor, a gift exchange (Cunningham 2016).

In effect, this relationship brings together the notion of sacrifice to the gods, where "sacrificium" usually implies "doing without something" or "giving something up" and, in metaphorical use, to describe doing good for others or taking a short-term loss in return for a greater gain later.

In more recent times, corporate philanthropy has gained renewed attention with the criticism of the welfare state and capitalism. According to some scholars, philanthrocapitalism would be "capable of solving the world's most deep rooted problems, a happy marriage of capitalism efficiency and entrepreneurship applied to disease and poverty, to higher education and the arts" (Cunningham 2016).

Other scholars discuss the ambivalence of philanthrocapitalism, recalling that "what may be most new about philanthrocapitalism is the very explicitness of the self-interested motives underlying large-scale charitable activities... what is most notable about the new philanthropy is the explicitness of the belief that as private enrichment purportedly advances the public good, increased wealth concentration is to be commended rather than questioned" (McGoey 2012).

\section{Theoretical Framework}

In this article, we rely on three theoretical frameworks: the interactionist perspective on giving, and as such, the gift economy (Mauss 1990); the relationship between corporate philanthropy and corporate social responsibility (Godfrey 2005); and the notion of meta-economic performance (Borré 2008, Borré and Gelmini 2008).

As Mauss (1990) pointed out in his celebrated work, giving, taking, and reciprocating form a three-part cycle of actions, and in this sense, giving is socially embedded and frequently prompts a counter gift. Godfrey (2005) suggests that, "(1) corporate philanthropy can generate positive moral capital among communities and stakeholders, (2) moral capital can provide shareholders with insurance-like protection for many of a firm's relation-based intangible assets, and (3) this protection contributes to shareholder wealth".

According to Borré (2008), the company's global performance comprises all the benefits that the owner of a share in the company expects to gain from the holding of the company itself. These benefits and positive results might be: (1) strictly financial and economic, i.e., positive results and cash flows that flow to the owner, directly via the company, in a fair and foreseeable length of time; (2) broader financial and economic results, i.e., positive results and cash flows that flow to the owner: a) not directly via the company (for instance, indirect advantages to the company's shareholders), or b) at a date later than the time when the effective pre-conditions for the results were created; (3) non-financial or non-economic results, such as social objectives (including recognition, prestige, social support, the cultural promotion of the social system the company operates in), 
environmental goals (for instance, reduction of environmental impact, improvement of the ecosystem), or more generally, competitiveness (ability to influence markets, strength with respect to customers, suppliers, competitors).

We define in our paper type (1) as economic performance, types (2) and (3) as meta-economic performance. In some cases, the meta-economic performance (type 2 or 3 ) of a period may generate strictly economic performance (type 1) at a later time, but in some cases, meta-economic performance does not produce financial flows within the company.

In accordance, we argue that patronage and corporate philanthropy generate an interactionist relationship between receiving and giving, suggesting that this relationship also produces a positive return for the donor, which could be monetary or of a more subtle and elusive type, namely meta-economic performance.

Lastly, although not explicitly referring to Pierre Bourdieu in this paper, his pivotal studies play a central role: first, his theory on the forms of capital can be applied to the question of the type of return that philanthropists receive from giving; second, in the context of 'world-making' entrepreneurial philanthropists, symbolic capital can be identified as a return on philanthropic giving; third, Bourdieu was one of the leading pioneers in framing gift-giving as reciprocity (the dynamic by which the giving of an object necessitates the reciprocal exchange of another gift); lastly, one of his pupils, Ostrower (1997), examined how the wealthy employ charitable giving as a source of symbolic capital to distinguish themselves from peers, thus characterizing elite philanthropy as a field in itself.

\section{Patronage in the Golden Age of Augustus}

\section{Horace in Brief and the Gift of Amicitia}

Quintus Horatius Flaccus (8 December 65 BC - 27 November 8 BC), known in the English-speaking world as Horace, was the leading Roman lyric poet during the time of Augustus (former Octavian). His career coincided with Rome's momentous change from a republic to an empire: an officer in the republican army, defeated at the Battle of Philippi in 42 BC, he was befriended by Augustus' right-hand man in civil affairs, Maecenas. From an economic perspective, the first iconic moment in the life of Horace was the loss of his father's estate in Venusia, confiscated for the settlement of veterans after the Battle of Philippi. Due to his growing amicitia (friendship) with Maecenas, he obtained from Augustus the sinecure $^{3}$ of scriba quaestorius, a civil service position at the Treasury, profitable enough even for members of the ordo equester (Nisbet 2007). Sometime between 34 and 33 BC, Maecenas gifted Horace the Sabine farm, probably not long after the publication of the first book of Satires. The gift, which included income from five tenants, would allow him to retire or at least spend less time at the Treasury.

\footnotetext{
${ }^{3}$ Generally a position requiring little or no work but giving the holder status or financial benefits.
} 
By this time, he had attained the status of eques Romanus, presumably as a result of his work at the Treasury (Nisbet 2007).

In this sense, Horace can be considered an artist who, also by virtue of his talent, received formal means of sustenance from the authorities - including the titles scriba quaestorius and eques - and a property. The relationship between the donors and the receiver did not explicitly entail a formal condition of reciprocity, as the artist would commemorate his donors if (and only if) he deemed it appropriate.

As White (2012) notes, "In general the resources which support a modern writer were negligible or nonexistent in Rome", since there was no mass market for the book trade, and neither royalties nor any kind of economic protection could be guaranteed to an artist after releasing a work, given that "anyone could copy his book and then sell or give it away; the sale of his books, therefore, would in any case scarcely have enriched a poet" (White 2012). Apart from some once-in-alifetime events (for instance, the secular games in $17 \mathrm{BC}$ ), Roman artists were unable to support themselves directly via their productions, but were affiliated with the upper class, as in the case of Horace, first as scriba quaestorius and then as eques Romanus. Through these services, poets would establish long lasting "ties of amicitia which yielded far greater rewards than any systems of fees or commissions would have done" (White 2012).

In this sense, some scholars prefer the term amicitia to patronage to signal the fact that the relationship is based mainly on elusive promptings of liberality rather than formal agreements (White 2012) ${ }^{4}$.

As such, poetry could be regarded as a career with a practical orientation, "Men with literary abilities found openings in Roman society that other men did not" (White 2012), especially via amicitia ties. In so doing, literary talent could provide access to the social élite, and thus to the benefits of friendship with the élite, from minor gifts to lucrative positions in private or public service. This type of direct or indirect support enabled artists to dedicate themselves fully to literature.

The gift of friendship, so meaningful for the analysis of Latin literature, assumes similarly attractive implications in the scientific realm.

In effect, and unsurprisingly, amicitia is widely mentioned by scientists when citing their protectors and givers.

For instance, in a passage in which the astronomer Copernicus expressed his gratitude to the friends that supported his studies, "The language is telling in its patronage-based implications: friendship and love were terms by which patronclient culture expressed its own relations. The client benefited from the patrons love by receiving things that could not be obtained in other ways. In turn, the tie between the two would be described as a friendship, insofar as their communications involved expressions of affection, confidentiality and familiarity" (Granada and Tessicini 2005).

\footnotetext{
${ }^{4}$ According to Bowditch (2001), "Augustus, by suggesting that Horace (with an eye to posterity) is potentially embarrassed by an intimate - familiaris - relationship with the emperor, ironically plays on the muddy distinction between patronage and friendship".
} 
Amicitia and amicus are in fact significant and familiar terms in Horace work, for instance, the book of Epodes opens with a salutation to "amice ... Maecenas", Odes 2.9.5 again features the rare syntagm of vocative amice and proper name (amice Valgi), and in Odes 2.6 and 2.7, amicus is reserved for the closing line (White 2012). Throughout Roman literary history, the language of friendship was the standard expression with which relationships between writers and the elite were described, implying voluntary associations based ideally on sentiment (White 2012).

With regard to Maecenas, amicus patron and friend, Nisbet (2007) notes that up to $17 \mathrm{BC}$, the key political personality, repeatedly mentioned by Horace and other great poets of the time (Virgil and Propertius, for example) was precisely Maecenas. Conversely, from $17 \mathrm{BC}$ onwards, references and poems were mainly dedicated to Augustus, especially by Horace. In this sense, Maecenas acted as a channel to convey to Augustus the emerging issues of land tenure, social justice, social values and priorities (Gold 2012). From 17 BC - the year of Horace's Carmen Saeculare (amongst others) - the task of poets changed from describing the issues and challenges of the incumbent's time to celebrating Augustus' role in solving them. In fact, in Carmen Saeculare, Horace moved "into panegyric, for the poet's mind was no longer engaged in wrestling with real problems; it was focused on the ingenious manipulation of themes of praise and panegyric for achievements already gained and issues now happily laid to rest" (Williams 2012).

A deeper understanding requires a more detailed look at Horace's relationship with Maecenas, both in terms of the importance for his work and the length of time of their amicitia (which lasted from an initial meeting in the year $38 \mathrm{BC}$ to their deaths in $8 \mathrm{BC}$ ).

In Horace's work, Maecenas and the benefits received are abundantly cited, in fact, 26 times in 162 poems according to White (2012). Horace called Maecenas his 'father' and 'king' (Epistles 1.7.37), and in turn described himself to Maecenas as a "friend who depends on and looks to you" (Epistles 1.1.105). Moreover, in the Epodes, in the first book of the Satires, in the Odes and the Epistles, Maecenas is addressed before anyone else, effectively making him the dedicatee of the respective books. He also elicited more over-appreciative invocations than anyone else (White 2012), for example, "O Maecenas, scion of ancestral kings, my bulwark and my sweet ornament" (Odes 1.1.1-2), "Maecenas, proud ornament and mainstay of my affairs" (Odes 2.17.3-4), "Maecenas, descendant of Etruscan kings" (Odes 3.29.1-3), "Maecenas, hailed in my earliest muse as you shall be in my last" (Epistles 1.1.1-3).

On the other side of the exchange, Horace pointed out the benefits he received, both indirectly (close association with Maecenas brought him public attention, which in turn probably contributed to the success of his poetry), and directly. In Epistles 1.7.15, he forthrightly admits "Maecenas, you made me rich", where the root sense of the word he uses for rich (locuples) is wealth in land and in writing, thus "Horace may have in mind the gift of property and specifically of his Sabine farm" (White 2012). However, this second segment of the circular relationship - the depiction of the benefits received - is nevertheless veiled, without a clear indication of 'what' and 'when' the gifts themselves were offered. 
Indeed, the relationship that emerges from a gift economy is complex, non-linear, with a disequilibrium both in time and in the amount of what is given and what is received.

\section{From the Gift of Amicitia to the Gift Economy ${ }^{5}$}

Bowditch (2001) starts her inspiring book on Horace by presenting an excerpt from the Epistle 2.1 to Augustus (here and later, the translation from Latin to English has been taken directly from her work while the original Latin text is in the footnotes).

Excerpt from Horace, Epistle 2.1 to Augustus, 257-270.

I have no patience for the service that burdens me, and I desire neither to be laid out anywhere in wax, with distorted features, nor to be celebrated in ill-formed poems, lest I blush presented with the boorish gift, and together with my poet, stretched out in a covered box, am borne into the street where they sell incense, perfume, pepper, and whatever else is wrapped in wastepaper.

As to the meaning of the Latin words, munera translates as munificence, and as stated in a number of Horace's works, the poet received dona (gifts) for his officia (services). ${ }^{7}$ The Epistle clearly demonstrates the diction of "the language of gifts and of services reciprocating benefactions, rather than a lexicon associated with coinage, buying, and selling" (Bowditch 2001). At the same time, this Epistle traces the line of gift patronage, whereas "the decorous gift of poetry presumably grows in value even as it ensures immortality" (Bowditch 2001), compared to a poetry marketplace, where poetry is nothing more than something "wrapped in wastepaper' and easily bought on the streets.

The gift economy that permeated patronage in the Golden Age is a topic of great modernity, conveying the elements of an economy not purely based on market inputs ${ }^{8}$. In particular, if the market calls for a formal exchange, a

\footnotetext{
${ }^{5}$ A gift economy is an economic system of exchange. According to Bowditch (2001), "The practice of debt-bondage, or nexum, constitutes an early form of contract law: the person receiving a loan temporarily relinquishes his person and its labor to the creditor until the debt is paid off'.

${ }^{6}$ Horace, Epistle 2.1 to Augustus, excerpt: "Nil moror officium quod me gravat, ac neque ficto in peius uoltu proponi cereus usquam nec praue factis decorari uersibus opto, ne rubeam pingui donatus munere et una cum scriptore meo capsa porrectus operta deferar in uicum uendentem ts et odores et piper et quicquid chartis amicitur ineptis".

${ }^{7}$ Munera (singular munus) derives from the root 'mei', meaning to (ex)change. In other words, a munus represents a gift carrying the obligation of an exchange (Bowditch 2001).

${ }^{8}$ According to Bowditch (2001), recalling the work of Mauss (1990), "The gift-exchange psychology underlying Roman patronage involves more than a competition for status. Though the rivalrous consumption and giving away of goods constitute a 'war of property', the obligation to receive gifts ensures the opposite - the creation of social bonds. Three related features of the process of gift exchange contribute to this creation of community or social interrelatedness: first, the tendency of the gift to pass to a third party in place of pure reciprocation; second, the tendency of the gift to increase in value - that is, the reciprocal gift is often larger than the initial one that elicited it; and third, the frequent 'intermingling' of souls and objects, as Mauss would
} 
concomitance of services and specific forms of remuneration, the gift economy is more elusive, as the exchange is not immediately perceivable as such, and the returns to the donor are of a specific kind, mostly non-monetary.

Horace would be creating, and in so doing, celebrating the dominant ideology of Augustus. In the notable words of Bowditch (2001) "The gifts, or munera, of public euergetism were a significant strategy by which both Augustus and the aristocratic elite cast an 'ideological veil' over their material base of power and thus successfully perpetuated it... That the tropes and conventions associated with literary patronage employ this same economic language suggests the degree to which poetry as a form of public expenditure similarly served the interests of ideology". In this sense, Augustus managed to keep power by having "charmed all with the sweetness of leisure" .

In a strictly economic perspective, the primary constituents of a gift economy are disequilibrium and the mystification of time. With reference to the former, the gift economy suggests a succession of munera and officia, which have elusive economic and mostly implicit emotional value, suggesting that the "impossibility of determining precise values leads each party to feel potentially still in debt to the other, thereby ensuring that the relationship continues" (Bowditch 2001). Moreover, along and across the lines of social status, "The recipient of a benefaction remains, in a sense, forever indebted to a benefactor of a higher order" (Bowditch 2001) ${ }^{10}$. With regard to the latter, the temporal delay between the first gift and its reciprocation binds the recipient to the donor, serving to mystify the economic aspect of this type of exchange. "Staggered and separated over time, the initial gift and its return appear spontaneous, voluntary, and unmotivated by the expectation of profit or the sense of obligation" (Bourdieu 1977).

The delay plays an increasingly central role, since it serves to "reproduce the relations of domination implicit in patronage by deflecting the necessity for return into the social sphere of gratia, with all its connotations of kindness, favor, and gratitude" (Bowditch 2001).

The bond, which is implicit in every relationship and exchange, is therefore of a voluntary and non-formal nature, and contributes to stimulating suggestions and networks of a more social than economic type. In fact, "The concomitant idea of 'social bonds' may be visible in the frequent language of 'binding' that appears in the prescriptive and epistolary material on social relations. That is, the contractual nature of debt-bondage and the libidinal bonds between persons, whether in a patronal relationship or in a more elite relation of amicitia between those of high

characterize it, that occurs when a person perceives the object given away as an extension of the self'.

${ }^{9}$ Tacitus, Annales 1.2, excerpt: "cunctos dulcedine otii pellexit".

${ }^{10}$ Seneca claimed that "to the [creditor for a benefit] I must make an additional payment, and even after I have paid my debt of gratitude, the bond between us still holds; for, just when I have finished paying it, I am obliged to begin again, and friendship endures" (Ben. 2.18.5). See also Oliensis (1998) who asserts, "if not literally in debt, he is in a condition of perpetual gratitude, the analogue of debt in the sphere of friendship". 
status, may reflect the two directions into which the archaic economy, as Bourdieu would have it, split in two" (Bowditch 2001).

The relevance of the gift economy to entrepreneurship and management is evident. Indeed, there are countless examples of economic and social relations that are not necessarily market-based, and are in fact developed and nourished through the consolidation of the donor's symbolic capital. Consider, for example, corporate giving and all the expenditures of organizations and individuals for non-profit purposes (culture, health, environment, sports and leisure management), all imprinted by the gift economy. As an example, in 2014, the Italian billionaire Diego Della Valle, CEO of Tod's (a worldwide leading corporation in the shoe industry), donated via a foundation \$33 million toward restoring the Colosseum in Rome. In so doing, he shifted responsibility for the preservation of Italy's monuments from the government to private philanthropists ${ }^{11}$.

The features of a gift economy clearly emerge from the disparity amongst parties and the uncertainty of the return (economic or non-economic) in favor of the donor, which is prolonged over time, thereby mystifying precisely - through time - the reciprocal relationship.

On the role of symbolic capital, if it implies, as in the lessons of Bourdieu, both the status that the giver accrues and the debt or obligation that a donation imposes on another, this capital embeds both its main affinities and distances from the gift to the market economy. On one side, a form of economic calculation is "very much present in classical man" (Bowditch 2001), and on the other, the relationship is mystified in terms of time and space, and employs an interconvertibility of material and symbolic capital that distinguishes the contours of the gift in respect of the market economy.

\section{Rehearsals of a Gift Economy: Augustus, Maecenas, and Horace on Stage}

\section{Methodology}

Our analysis is based on the literary works of the Latin poet Horace who lived in the Golden Age of Augustus, and was both one of the purest exempla of poetry and a recipient of important gifts via patronage from his patrons. We adopt a case study methodology to disentangle some of his poetic lines to propose a patronage and gift economy framework as the building blocks of corporate philanthropy and corporate social responsibility actions.

We chose Horace as our case study, as he "addressed poems or otherwise paid compliments to over sixty of his contemporaries, and he treated of social relationships in every sort of verse he wrote. He thus created a more detailed representation of his milieu than we have from any other Roman poet" (White 2012) $)^{12}$.

\footnotetext{
${ }^{11}$ From The Independent online, 7 September 2014.

${ }^{12}$ Another giant in Latin literature, and close friend of Horace, was Virgil. Relevant gift economy traits are also present in his works. Consider, for instance, the celebrated Eclogue 1 that depicts the
} 
We rely heavily on the seminal work of Bowditch (2001) and adopt her cultural approach. At the same time, we recognize that the deliberate use of works of literature as social documents might be problematic, thus calling for caution.

\section{The Gift Economy in Action: The Sabine Farm}

Maecenas gifting Horace the Sabine farm was certainly a form of economic return to the poet's benefit who in turn would celebrate the donor in his works. However, a more detailed analysis shows that Maecenas also imparted Horace with social status, thus bringing the artist closer to the ruling class: "Maecenas's gift of land to Horace - an economic or material value - had the far more important symbolic value of lending the poet the status of a landholder, a man of independent means; expenditure such as this, in turn, creates the symbolic capital that encourages Horace to celebrate his patron, creating the ultimate cultural value of Maecenas's immortality" (Bowditch 2001).

Indeed, Horace considerably emphasized this social status. "This loan of status, by which the gift reflects both on the recipient and back on the giver, is apparent in Horace's frequent use of the word decus to describe Maecenas in relation to himself: 'glory', 'ornament', 'honor' - the range of meanings suggests the honor that Maecenas confers on the poet through association with him and by his benefactions to him, as well as the glory that the poet reciprocates by honoring his patron in his poems" (Bowditch 2001).

However, social status is a mantle that must be worn in public to be appreciated as such, a gift that offered the poet glory and immortality. Thus, an audience of spectators is needed to capture the importance of the exchange. In other words, in the gift economy, the exchange - even if non-economic - is perfected in its exhibition. "This reciprocal exchange of status, in which giver and receiver are both distinguished by the gift, depends on a third party to witness the transaction ... Status depends, to some degree, on the envy of those who possess less" (Bowditch 2001).

Once again, useful suggestions emerge for corporate philanthropy: Philanthropists and corporations invest in corporate social responsibility actions (also) for their non-economic returns and the positive visibility that ensues.

dialogue between two shepherds. The first, Meliboeus, is forced to leave his homeland for reasons unspecified, and the second, Tityrus, rests in the shade of a beech tree singing in the breeze, having managed to keep his possessions thanks to the intervention of a young god. According to Bowditch (2001), "By presenting Tityrus's good fortune as the result of benefaction rather than a market economy, and by displaying the ineffectiveness of the latter when the shepherd wishes to buy his freedom, the poem essentially demonstrates the 'inevitable' necessity of patronage as a socioeconomic system". Furthermore, in Virgil, the excess of gratia in the gift economy also emerges: whereas he mentions, also in Eclogue 1, maiora (major) topics to be sung, the comparative strongly connotes the idea of excess or surplus value associated with gratia, alluding to "the paradox that gratia, though returned, leaves behind an excess or residue, a trace of itself-something that, in fact, causes the favor to increase in value" (Bowditch 2001). 
Consider, for instance, Asian tycoons who acquire North American sports clubs to gain legitimacy and increase their credibility in the international scenario. ${ }^{13}$

The gifting of the Sabine farm encapsulates the key features of the gift economy, positioned perfectly in the chronology of gifts and counter-gifts between Horace and his benefactors. Indeed, the Sabine farm itself was probably a benefaction constituting an expression of gratia from Maecenas for Horace dedicating the Satires to him and for the ideological value of the poems. "Thus, as both a reciprocating benefaction for past services and a gift that continued to lay a claim on Horace, the estate symbolizes that very ambiguity and disequilibrium of debt so characteristic of a gift economy" (Bowditch 2001).

In line with Mauss (1990), a material gain, such as the Sabine farm, generates the symbolic capital of gratitude, which in turn becomes poetry that reaches an audience beyond the patron and contributes to the production of the dominant ideology.

In addition, Horace's depiction of the Sabine farm "suggests an ideology about the artist and aesthetic production that simultaneously depends on, competes with, and often appropriates the terms of the socioeconomic discourse of patronage...on the one hand, the farm invokes the discourse of patron-client reciprocity - the very real gratitude that the Horatian speaker represents himself as feeling toward his benefactor, as well as the need to requite his gifts; on the other hand, the farm, the very gift that obliges, simultaneously allows Horace the liberty to renegotiate his debts" (Bowditch 2001).

Similarly, the above examples of wealthy and private philanthropists (from Della Valle to Tsai) convey on the one hand the evocative capacity and noneconomic return of the investment (in particular, the increased visibility of philanthropists), and on the other hand, the artistic or athletic gesture, once executed, transmutes into something else, which in itself justifies and goes well beyond the mere relationship of reciprocity.

Such gestures, in fact, once outside the precise spatial and time specific context in which they are placed, turn into symbols - effective, as they are visible and tangible - of the biunivocal nature of the telationship, always evident, in the gift economy.

Starting from these premises, Satires 2.6 is traditionally considered as Horace's thanksgiving letter to his patron for the Sabine farm, even if Maecenas is not explicitly mentioned. Below a key excerpt.

Excerpt from Horace, Satires 2.6, 1-15.

This was in my prayers: a measure of land not so large, with a garden and near the house a spring of pure water and above this [in addition] a little patch of woods. The gods have given me more and better. It is good. I ask for nothing more, son of Maia,

\footnotetext{
${ }^{13}$ From The New York Times online, 14 August 2019: "Joseph Tsai, a co-founder of Alibaba, the Chinese internet giant, is closing in on a record-breaking deal to gain sole ownership of the Nets, continuing a momentous off-season for a franchise making its most significant steps toward emerging from the shadow of the neighboring Knicks. The Nets deal, valuing the team at \$2.35 billion, will set a record for the purchase price of a sports franchise".
} 
except that you make these gifts lasting [truly mine]. If I neither make my property greater by crooked calculation, nor have diminished it through the vice of waste, if foolishly I pray for none of these things: "Oh, if that nearby corner could be added, which now skews my farm's shape! Oh, if lucky chance would reveal to me a pot of money, as it did for him, who once the treasure was found plowed the same field as an owner which he had as a hired laborer, made wealthy by his friend Hercules!" If what is here now pleases me, grateful for it, with this prayer I ask: fatten the master's flock and all else but his talent, and, as you are accustomed, always be my greatest guardian. ${ }^{14}$

The opening is decisive wherein Horace claims that with the Sabine farm, the gods have given him "more and better". On one side, Horace's prowess is such that giving thanks for the gift is beautifully concealed, since neither the donor (Maecenas) nor the gift (the farm) are explicitly mentioned. On the other side, the fact that reference is made to a gift from the gods, and that this gift exceeds the poet's wishes signal the importance of the gift and its excess, charming the reader with ars poetica.

Immediately after, rather surprisingly, the poet directly addresses the Son of Maia, Mercury, the God of commerce: the change of perspective, quite pronounced, introduces into the Satires the link between the gift received and the expectations that weigh on the poet. In other words, addressing the God of commerce means that the speaker "voti damnatus by the grant of the estate, is in the very condition of obligation that provided, according to Marcel Mauss's early speculations, the origin of a contract, of nexum and action" (Bowditch 2001) ${ }^{15}$. However, the relationship emerges via a metaphor, rendering it nuanced, inferred.

In another perspective - since Mercury is associated with gain, luck, commerce, and communication - Horace calls upon this God to enhance his poetic works and bring himself financial gain.

The substantial theme of the poem, from a more general point of view, is the antithesis between the city and the countryside: Rome, where a few years earlier Horace was able to isolate himself in his moral meditation and poetry, no longer provided him any serenity or joy when he became famous and amicus to the powerful. As such, the poet was bothered by the petulant crowd, impatient with those who envy, and wanted only a quiet life: rather than an opulent home, luxury goods, refined furniture, and valuable dogs, he preferred parsimony and the simple food of the farm.

\footnotetext{
${ }^{14}$ Horace, Satires 2.6, excerpt: "Hoc erat in votis: modus agri non ita magnus, hortus ubi et tecto vicinus iugis aquae fons et paulum silvae super his foret. auctius atque di melius fecere. bene est. nil amplius oro, Maia nate, nisi ut propria haec mihi munera faxis. si neque maiorem feci ratione mala rem nec sum facturus vitio culpave minorem, si veneror stultus nihil horum 'o si angulus ille proximus accedat, qui nunc denormat agellum! o si urnam argenti fors quae mihi monstret, ut illi, thesauro invento qui mercennarius agrum illum ipsum mercatus aravit, dives amico Hercule!', si quod adest gratum iuvat, hac prece te oro: pingue pecus domino facias et cetera praeter ingenium, utque soles, custos mihi maximus adsis".

${ }^{15}$ In this sense, Bowditch explicitly cites Mauss (1990) who writes, "The mere fact of having the thing puts the accipiens in an uncertain state of quasi-culpability (damnatus, nexus, aere obaeratus), of spiritual inferiority and moral inequality ... in relation to the one delivering the contract".
} 
The modernity of the text and the comparableness with the philanthropic/ corporate social responsibility mechanisms is evident: on the one hand, Horace complained about city life in the Augustan era, but at the same time, paid homage to Augustus, and implicitly paid tribute in his work to the peace and resolution of conflicts that Augustus brought with the empire. In this dialectic, ars poetica operates as a legitimizing agent.

Similarly, on 19 August 2019, the Business Roundtable (comprising the CEOs of the largest US corporations) announced the release of a new 'Statement on the Purpose of a Corporation' that includes all stakeholders (customers, employees, suppliers, communities, shareholders) as essential parts of any business ${ }^{16}$. In this sense, the Statement acts as a networking and legitimizing agent amongst two endpoints; the quest for profit (from the Business Roundtable) and the petition for greater awareness of the integrated dynamics of corporations (from society as a whole).

As in Horace's verses, the complexity of the conjunction is evident, rendering the balance between the different instances fragile and intricate ${ }^{17}$.

\footnotetext{
${ }^{16}$ Statement on the Purpose of a Corporation (from the Business Roundtable website): "Americans deserve an economy that allows each person to succeed through hard work and creativity and to lead a life of meaning and dignity. We believe the free-market system is the best means of generating good jobs, a strong and sustainable economy, innovation, a healthy environment and economic opportunity for all. Businesses play a vital role in the economy by creating jobs, fostering innovation and providing essential goods and services. Businesses make and sell consumer products; manufacture equipment and vehicles; support the national defense; grow and produce food; provide health care; generate and deliver energy; and offer financial, communications and other services that underpin economic growth. While each of our individual companies serves its own corporate purpose, we share a fundamental commitment to all of our stakeholders. We commit to: Delivering value to our customers. We will further the tradition of American companies leading the way in meeting or exceeding customer expectations. Investing in our employees. This starts with compensating them fairly and providing important benefits. It also includes supporting them through training and education that help develop new skills for a rapidly changing world. We foster diversity and inclusion, dignity and respect. Dealing fairly and ethically with our suppliers. We are dedicated to serving as good partners to the other companies, large and small, that help us meet our missions. Supporting the communities in which we work. We respect the people in our communities and protect the environment by embracing sustainable practices across our businesses. Generating long-term value for shareholders, who provide the capital that allows companies to invest, grow and innovate. We are committed to transparency and effective engagement with shareholders. Each of our stakeholders is essential. We commit to deliver value to all of them, for the future success of our companies, our communities and our country".

${ }^{17}$ In the notable words of Oliensis (1998), "One of Horace's distinguishing features as a poet, and one of the qualities that attracts me to his poetry, is the degree to which he confronts his own implicated and compromised position within society while maintaining the independence of his poems. The final sum of Horace's calculations, in any event, is the making of good poetry, by which I mean poetry that is not exhausted in or fundamentally compromised by the social exchanges in which it participates. That is the kind of poetry, so far as we can tell, that would be likely to please Maecenas. And it is the poet's best means of making his face".
} 


\section{The Cornucopia, when Words Legitimize Power}

Odes 1.17 contains some important indications of Horace's approach to power and the role of the receiver towards his donor in a gift economy, in particular, the relevance of some non-economic returns for the donor and the legitimizing process via ars poetica. Below the first lines.

Excerpt from Horace, Odes 1.17., 1-28.

Often Faunus swiftly changes Lycaeus for lovely Lucretilis and all the while keeps the fiery heat and rainy winds away from my goats. Throughout the protected grove, safe from harm, the wives of the smelly he-goat stray seeking the hidden arbute and thyme, and the kid-goats fear neither green snakes nor warlike wolves, when, Tyndaris, the sloping valleys and smooth rocks have sounded deeply with the sweet panpipe. The gods protect me, my reverence and my Muse are dear to them. Here lush abundance of the riches of the country will flow to the full for you from the generous horn. Here, in a hidden valley, you will avoid the heat of the Dog Star, and on Teian lyre will sing of Penelope and glassy Circe contesting over one man. Here, in the shade, you will drink glasses of innocuous Lesbian wine, and Bacchus, son of Semele, will not mix in wars with Mars, and you will have no fear of impudent Cyrus, that he might attack you, unfairly matched, with unrestrained hands and tear the garland, clinging to your hair, and your innocent clothes ${ }^{18}$.

In her inspired interpretation, Bowditch (2001) points out that the central stanza of the poem, particularly the words: "The gods protect me, my reverence and my Muse are dear to them. Here lush abundance of the riches of the country will flow to the full for you from the generous horn", fully reflect the dynamics of patronage. First, the gods protecting Horace call forth the gifts of the regime, and second, the cornucopia (horn of plenty) explicitly ties the abundance of the gods to patronal relations and the plenty of pax Augusta (Bowditch 2001) ${ }^{19}$.

The dynamics of the relationship developed in the following way: Maecenas, the beloved friend, the expression of the gods, through his benevolence ascribed to Horace an abundance of gifts, in turn, the poet, via the gifts and ars poetica, transmuted the gifts into songs that celebrated both pax Augusta and Maecenas.

We next examine two interpretations, both plausible, for a better contextualization and some managerial implications.

\footnotetext{
${ }^{18}$ Odes 1.17 excerpt: "Velox amoenum saepe Lucretilem mutat Lycaeo Faunus et igneam defendit aestatem capellis usque meis pluviosque ventos. Inpune tutum per nemus arbutus quaerunt latentis et thyma deviae olentis uxores mariti nec viridis metuunt colubras nec Martialis haediliae lupos, utcumque dulci, Tyndari, fistula valles et Usticae cubantis levia personuere saxa. Di me tuentur, dis pietas mea et Musa cordi est. Hic tibi copia manabit ad plenum benigno ruris honorum opulenta cornu; hic in reducta valle Caniculae vitabis aestus et fide Teia dices laborantis in uno Penelopen vitreamque Circen; hic innocentis pocula Lesbii duces sub umbra nec Semeleius cum Marte confundet Thyoneus proelia nec metues protervum suspecta Cyrum, ne male dispari incontinentis iniciat manus et scindat haerentem coronam crinibus inmeritamque vestem".

${ }^{19}$ The horn of plenty could lead to a more negative understanding, for instance, in the case of libidinal excess (Bataille 1985); ars poetica is deemed to limit and transmute this potential excess into art (Bowditch 2001).
} 
According to some authors, Odes 1.17 captures Horace's personal characteristics as a young republican militant in the army of the Cesaricides. Then, falling into the Prince's circle of patrons and friends, Horace provided his contribution, as a civil poet, to the consolidation of the Augustan regime, seen as a guarantee of public peace and inner tranquility for those who prefer withdrawing into the private sphere and pursue an ideal of individual perfection (Nuzzo 2006). In addition, Odes 3.14 celebrates pax Augusta with the lines: "This day of celebration will drive away my pains: I am no longer afraid of riots nor violence of death, now that Caesar reigns over the world"20. With these words, Horace clearly shows that in his eyes, civil and personal motives are linked: the Roman people announced the victorious return of Augustus from the expedition to Iberia and were invited to celebrate this day as a festive occasion, freeing them from worries and fears; a festive day especially for the poet, as he felt safe as long as the Prince exercised his power (Nuzzo 2006).

In an alternative interpretation, leaving aside the authenticity of Horace's sentiments, in a gift economy, the (non-monetary) return for the donor is the celebration, and in so doing, the receiver of the gift legitimizes his power.

While the two interpretations are intertwined, even in the context of personal feelings of sincere approval of pax Augusta, Horace was aware that his ars poetica would act as an agent of legitimacy of the power in force. As such, in a broader perspective, patronage acts as a legitimizing process also in relation to corporate practices from social reporting to philanthropy.

In effect, corporate philanthropy, originally aligned with altruistic intention, should be used as well to deflect criticism from industries with reputations for poor environmental, social, or economic management.

Legitimacy theory, in effect, relies on the notion of a social contract between a company and the society in which it operates through various means, such as philanthropy, and social actions and disclosure as legitimation tools. At the same time, the literature suggests that large and publicly-owned companies particularly engage in corporate social responsibility activities and reporting because they are more visible and open to public scrutiny, hence with greater legitimacy needs.

The attitude to entrepreneurial philanthropy, the sponsorship of cultural events, supporting environmental and social issues, all reflect the same patronage mechanisms: on one side, the donor, and on the other side, the receiver, with a strategy of rewards and returns not necessarily in monetary terms.

Augustus measured the performance of his patronage via the enhanced consensus that Horace helped to nurture with his ars poetica. Similarly, corporate social responsibility policies express performance, not only in economic terms, but the greater visibility, social consensus, social cohesion, and acceptance of the corporation itself.

Nevertheless, non-monetary returns are difficult to measure, often emerge over a period of time, and are not necessarily received by the initial donor, in short, they are more elusive and problematic to capture through the usual cash

\footnotetext{
${ }^{20}$ Odes 3.14 excerpt: "Hic dies vere mihi festus atras eximet curas: ego nec tumultum nec mori per vim metuam tenente Caesare terras".
} 
inflows and outflows measurements ${ }^{21}$. However, unlocking the covert meanings of economic acting requires understanding the close interdependence between the economic factors, social factors, and corporate social responsibility expressions (as in the sponsorship of ars poetica $)^{22}$.

\section{The Disequilibrium amongst Parties, Patronage at Stake}

If the Sabine farm was the gift received in answer to his prayers to the gods, the munera lured Horace (Satires 2.6 and Odes 1.17), and even if the plenty of pax Augusta was celebrated and truly welcomed (Odes 3.14), at a certain stage the relationship between Horace and Maecenas, rectius his patron along with Augustus, took a more articulated path, an evocative managerial interpretation. Below some lines form the Epistles 1.1 that first trace the new direction of patronage.

Excerpt from Horace, Epistles 1.1, 1-12.

By my first Muse glorified, to be glorified by my last, you, Maecenas, seek to confine me again in the old school, though I have been gazed upon enough and already awarded the foil. My age, my temperament are not the same. Veianius, having hung up his arms at Hercules' temple door, hides, concealed in a field, to avoid beseeching the crowd, repeatedly, from the edge of the arena. There is voice constantly sounding in my cleansed ear: "Wisely free the aging racehorse in time, lest he stumble at the very end, short of breath, a sight to be mocked." And so, I now set aside poems and other frivolous pursuits. The true and the proper, this is my care and query, and I am completely involved in this; I am storing up and setting in order those things which soon I may bring out to use $\mathrm{s}^{23}$.

\footnotetext{
${ }^{21}$ Interestingly, on the monetary/non-monetary returns Kräussl et al. (2016) point out, "Determining the fundamental value of an artwork is almost an impossible feat in itself. Under rational expectations, the fundamental value of an asset equals its discounted expected stream of cash flows (present value theory). It is relatively easy to obtain the expected cash flow earned by owning a share of stock (dividend) or a piece of real estate (rent). The ownership of an artwork, on the other hand, provides no claim for monetary return but some kind of convenience yield, which is also described as a "dividend of enjoyment".. and as "esthetic pleasure" .. Thus, reasons closely dependent on the motivations and characteristics of the owner make it impossible to clearly quantify the return on art".

${ }^{22}$ According to Campa et al. (2019), "The intersection between the arts and business is an interesting domain of study, considering the non-rational nature of the arts and the rationality that is often associated with business ...The traditional principle of 'art for art's sake' assumes that arts institutions and artists should not be overly dependent on business if they are to be viewed as legitimate". Similarly, for Lewandowska (2018), "[corporate philanthropy] programs based on development through the arts should be subjected to detailed and systematic review, and their methods - critically analyzed, so as not to become unsubstantiated promises or glamorous dummy, using arts in an instrumental or cynical way".

${ }^{23}$ Horace, Epistles 1.1, excerpt: "Prima dicte mihi, summa dicende Camena, spectatum satis et donatum iam rude quaeris, Maecenas, iterum antiquo me includere ludo? non eadem est aetas, non mens. Veianius armis Herculis ad postem fixis latet abditus agro, ne populum extrema totiens exoret harena. est mihi purgatam crebro qui personet aurem: 'solve senescentem mature sanus equum, ne peccet ad extremum ridendus et ilia ducat.' nunc itaque et versus et cetera ludicra pono: quid verum atque decens, curo et rogo et omnis in hoc sum: condo et conpono quae mox depromere possim".
} 
Two premises should be made. First, the Epistles came later than the Satires and Odes in the poet's life, and some commentators have argued that Horace was becoming less tolerant of the commitments of social life, feeling old age approaching. At the same time, without tackling the perplexity of the relationship between artists and power, Lee-Stecum (2009) believes that "the careful definition and in some cases active re-definition of power and freedom is at the heart of the ethical and social program of Horace's first book of Epistles", and that in those poems "the poet's concern with independence as a heartfelt expression of his desire for poetic freedom inspired by the changing circumstances of his life and social environment".

Based on these premises, the first four lines depict a diminishing weight of the debt of patronage: if Maecenas was glorified at the beginning of Horace's career, the relationship descended and the debt transmuted, since poetry came first ${ }^{24}$.

The reversal of the approach is such that the symbolic capital accrued by Horace through his celebration of Maecenas overturned the debt that Maecenas incurred in depending on the poet for immortality, inverting the hierarchy of patronage. "Aesthetic values have priority over the social or political officia of a dependent" (Bowditch 2001). Indeed, Horace used the metaphor of a retired gladiator who was bound (addictus) to his labor: now both retired, and in this sense, the economic meaning reinforcing Horace's point of view of an obligation already in the past, no longer incumbent ${ }^{25}$. The setting is then turned upside down: via Horace's ars poetica, Maecenas was made immortal, and then Horace dedicated himself to philosophy, hence reversing the relationship, and art reshaped the debt that was now the sole burden of the patron.

As mentioned, the disequilibrium and the alternation of debt provides some practical managerial implications. First, it is of certain interest for corporations to know in advance that their philanthropic activities carry the significant risk of not succeeding. What happens if the project fails to achieve monetary (and nonmonetary) returns?

Corporate social responsibility projects, as well as patronage, face an imposing risk of failure, which in turn, rebus sic stantibus, deteriorates the cost of capital of corporations. Recent studies (e.g., Judd and Lusch 2018) find that, on average, when firms make large philanthropic donations, they experience an increase in their cost of capital. However, this effect, even if only partial, is mitigated by firms that have lower agency costs and are able to use corporate giving as a marketing tool. Other authors (e.g., Zolotoy et al. 2019) posit, with

\footnotetext{
${ }^{24}$ Bowditch (2001) offers a relevant interpretation of the lyric and its rhythm: "Maecenas has received the first dedication and, rest assured, the line implies, he is to receive the last. But Horace's poetic inclination comes first, both in the line and in his generic choice (Prima ... Camena); it centers the line, implying that obligations diminish from this summit. By thus manipulating the dedicatory convention, Horace grounds the overt justification for refusing his patron".

${ }^{25}$ According to Bowditch (2001), "Horace takes images from the embedded economy of public expenditure on the gladiatorial munera and uses them to suggest the economic calculation behind patronage: he has already...earned his withdrawal from public themes and performance, and thus he has paid off his debt".
} 
mixed results, that philanthropy-based inferences reduce investors' agency concerns, and as such, reduce the cost of capital.

However, the corporation's acknowledgment that the return of its social and cultural investments may not be attained could also be interpreted, from a management strategy point of view, as an expression of the (only apparent) willingness of the corporation to detach itself, at least in pure form, from the achievement of a specific and strictly positive return, whether monetary or not. Corporations are prepared and therefore accept the risk implicit in this strategy to assume the absence of returns (economic or not) from their investments. This in turn becomes beneficial, in strictly utilitarian terms, precisely because corporations are acting - in the community's perception - for the common good, regardless of the tangible results in their favor. In other words, a return always ensues, either specific (in monetary terms or not, as for instance reputation, good standing or cultural respectability) or in the form of the absence of a specific return (generically). In effect, Augustus and Maecenas could have easily borne Horace's progressive detachment over time in terms of the credibility of his role as a poet during pax Augusta.

Another area for discussion that arises from Epistles 1.1 is the challenge in expressing - in absolute terms - the volume of contributions received and the returns rendered.

The issue of measuring the impact of philanthropic activities is becoming highly divisive in management research. Some scholars - based on the usual valuation models exclusively for profitable activities - deem it advisable to adopt mechanisms such as SROI (Social Return on Investment). This index, deriving from the analysis of accounting and financial statements, necessarily requires translating into monetary terms the outcomes of the corporate social responsibility activities, whereby monetary value is assigned to the outcomes through determining the financial values that help demonstrate to stakeholders the importance of every outcome of the corporation's production. Therefore, this involves defining economic proxies for assets that often do not have a market value, also considering that for some goods (Horace's lyrics, for instance), there is no objective cost, but the result of subjective perceptions, thus highly problematic. In their broad review of the pros and cons of SROI, Maier et al. (2015) identify two fundamental limitations, namely adherence to a strictly utilitarian approach and eagerness for commensuration.

Regarding the approach, "SROI analysis is clearly indebted to the utilitarian idea that the proper course of action is the one that maximizes utility. This approach to ethics can be criticized from numerous perspectives, e.g. from a Kantian perspective, which suggests that it is not the consequences of an action that make it right or wrong but the motives of the person carrying out the action" (Maier et al. 2015).

With reference to the issue of commensuration (the comparison of different entities according to a common metric), "In SROI analysis qualitative issues are quantified, translated into monetary values, and compared to each other. Commensuration is never a neutral approach but inherently political. SROI analyses are particularly poignant in that they involve monetizing and comparing 
things that are often regarded as priceless and unique, like human lives, health or nature" (Maier et al. 2015).

The last managerial implication that emerges from the dichotomous relationship (in terms of patronage) between Maecenas and Horace, as developing in Epistles 1.1, is the absence in their relationship of a market mechanism able to regulate and institutionalize patronage, and more in general, philanthropic activities.

It is indisputable that the arts (and the art market) live in a context of economic uncertainty, mainly due to the independence of the quality assessment of the object from (most) of its intrinsic properties. "In the art market, quality is an intersubjective property that emerges from the contingent assessment of the artworks by the actors in the market and does not exist independently from it; interactions between actors allow the artistic significance of an artist or one of the artworks by that artist to be evaluated and for quality to be assessed" (Beckert 2020).

If the quality of artworks is the outcome of judgements from relevant actors in the market - buyers (museums, private collectors), sellers (artists, galleries, auction houses), and intermediaries (Beckert 2020) - then the value and preferences are not a reflection of individual taste, but an endogenous outcome of the market process, socially shaped (Beckert 2020).

Corporate philanthropy must therefore be placed within a context of market players who should be able, at least collectively, to assess the quality of the outcomes of philanthropy itself, albeit not necessarily in monetary terms. The participation of several actors on the stage (corporations, not-for-profit organizations, collectivity, government, stakeholders in general) therefore contributes to mitigating, at least in part, the intricacies of measuring outcomes in numerical terms: instead, the economic value of each outcome should emerge from close negotiations between the different stakeholders. This aspect makes the context of patronage, at least its occurrence during pax Augusta, significantly different from corporate philanthropy, and a point of distinction between the two paradigms ${ }^{26}$. At the same time, the sounding board that the social interlocutors currently have at their disposal - also relative to negative discourses (for instance, corporate reputation) - is of course very different in terms of depth and range, from social networks to the Internet, and far less under the control of the donor and receiver.

As mentioned in the introduction, furthermore, Horace is a truly and entirely modern man. His continuous tension between public life and ars poetica has been variously interpreted, by scholars, in relation to his knowledge of Epicurean philosophy.

\footnotetext{
${ }^{26} \mathrm{~A}$ further difference between the gift economy/patronage and corporate philanthropy is the absence, in the case of pax Augusta patronage, of the need to conveniently allocate scarce resources. Conversely, in the case of the corporate philanthropy, corporations must always deal with this dimension, as they do not have unlimited financial resources to invest.
} 
This is certainly not the place to investigate whether and what was his relationship with Epicurus (who, as is well known, despised poetry) and his philosophy, which Horace certainly knew and was influenced by.

Certainly he had no interest in physics and cosmology, which so passionately interested Lucretius, while at the very same time certainly the moral precepts of Epicureanism were repeatedly discussed and appreciated by him, although without any claim to systematicity and consistency (La Penna).

In other words, Horace's relationship with Epicureanism appears to be based not so much on a strict doctrinal adherence to the philosophical principles of the school, as on a deep, intimate consonance with an ideal of wisdom, on the sharing of a sober style, of an overall vision of life and the world, on an interiority that knows how to catch the essential in every situation and in every human event (Monaco 1992).

Whether he was an Epicurean or not, the continuous dialectic between a convinced adherence to the "world outside" compared to art and his own interiority make Horace a modern man, so well inserted in the dynamics of our time.

\section{Conclusion: Managerial Implications and Future Research Avenues}

The life of Horace, one of the leading poets of the Golden Age of Latin literature, was characterized by a fruitful and multifaceted relationship with power (also from an economic perspective), nuancedly epitomized by Augustus and more directly by Maecenas.

The iconic traits of the relationship between ars poetica and power are well depicted in some key lines of his poems: first, the explicit acceptance of the munus of the Sabine farm (Satires 2.6), then the persuasive and persuaded exaltation of pax Augusta that honored Horace with the horn of plenty (Odes 1.17), and final, sober demeanor, towards his old age, at that time well aware of both the gifts received and his talent for transforming them into pieces of immortality (Epistles 1.1).

To reveal the relationship between Horace and power, we have made use of an economic approach to patronage and the gift economy compared to the market economy. In other words, the gifts that Horace received were (more than) returned with his poetic work through a dyadic, complex, non-linear mechanism in a dynamic and continous relationship of alternation of debt between the patrons and Horace.

Through adopting a multidisciplinary and organic approach, this study provides some elements of novelty. On one hand, the findings enable Latin literature scholars to better understand the economic phenomena that, at least in part, inspired and influenced the life and art of Horace, in both his human and personal sphere. On the other hand, from a managerial perspective, the nexus between patronage, the gift economy, and corporate philanthropy is elucidated.

First, while patronage enables the development of an economic relationship, even if in a non-linear, multi-faceted, and not always immediate way, corporate 
philanthropy induces relationships aimed at fostering positive results for the donor, be they economic or meta-economic, instantaneous or delayed.

The managerial implications are evident for non-profit corporations (engaging in cultural or humanitarian efforts) and some industries - for example, sports where economic returns may not be a central element of the investment. In this sense, the gift economy as a theoretical framework, widely known in other research fields, is a relevant framework for the management domain. In particular, as in the gift economy, corporate philanthropy and corporate social responsibility express an elusive kind of economic relationship not punctuated in time or space, but with elements of significant value for both. This relationship implies intricacies with regard to the conventional measures of investments generally based on precise, analytical, and measurable data of cash inflows and outflows. In the case of corporate philanthropy, the results are not only uncertain, but challenging to measure with the usual monetarization mechanism.

Furthermore, Horace - even if profoundly rooted in the ars poetica of the Latin Golden Age - stands as well as a paradigmatic exemplum of modernity, especially in his diachronic and polymorphous relationship to public engagement.

Finally, this paper has some limitations that provide interesting avenues for future research. In particular, our case study focuses on only Horace, even if a preeminent poet of Latin literature. Likewise, we do not examine a specific corporate philanthropy strategy reconstructed via the gift economy framework. As such, fruitful venues of future research include enlarging the spectrum of economic activities to be disentangled via the gift economy framework, and developing indepth case studies of specific corporate social responsibility and philanthropy actions.

\section{References}

Bataille G (1985) Visions of excess: selected writings, 1927-1939. Minnesota: University of Minnesota Press.

Beckert J (2020) Markets from meaning: quality uncertainty and the intersubjective construction of value. Cambridge Journal of Economics 44(2): 285-301.

Borré L (2008) L'avviamento in aziende con carenza di reddito. (Non performing corporations and goodwill). Giuffrè Editore.

Borré L, Gelmini L (2008) Goodwill, negative margins and results: some evidence from the professional football industry. Journal of Business \& Policy Research 4(1): 1-12.

Bourdieu P (1977) Outline of a theory of practice. Cambridge: Cambridge University Press.

Bowditch PL (2001) Horace and the gift economy of patronage. California: University of California Press.

Campa D, Wilhelmina E, Zijlmans A (2019) Corporate social responsibility recognition and support for the arts: evidence from European financial institutions. European Management Journal 37(6): 818-827.

Cunningham H (2016) The multi-layered history of Western philanthropy. In The Routledge Companion to Philanthropy, 62-75. Routledge.

Fioravante P (2010) Corporate philanthropy: a strategic marketing consideration. Journal of Applied Business and Economics 11(3): 91-96. 
Godfrey P (2005) The relationship between corporate philanthropy and shareholder wealth: a risk management perspective. Academy of Management Review 30(4): $777-798$.

Gold B (2012) Literary and artistic patronage in ancient Rome. Texas: University of Texas Press.

Granada M, Tessicini D (2005) Copernicus and Fracastoro: the dedicatory letters to Pope Paul III, the history of astronomy, and the quest for patronage. Studies in History and Philosophy of Science Part A 36(3): 431-476.

Judd SJ, Lusch SJ (2018) Corporate philanthropy and the cost of equity capital. SSRN.

Kidd A (1996) Philanthropy and the social history paradigm. Social History 21(2): 180 192.

Kräussl R, Lehnert T, Martelin N (2016) Is there a bubble in the art market? Journal of Empirical Finance 35(Jan): 99-109.

La Penna A (1993) Saggi e studi su Orazio. (Studies and essays above Horace). Sansoni.

Lee-Stecum P (2009) Persona and power in Horace's first book of Epistles. Antichthon 43(Jan): 12-33.

Lewandowska K (2018) Policy versus philanthropy: between public and private funding of the arts. Edukacja Ekonomistów i Menedżerów 50(4): 97-111.

Maier F, Schober C, Simsa R, Millner R (2015) SROI as a method for evaluation research: understanding merits and limitations. VOLUNTAS: International Journal of Voluntary and Nonprofit Organizations 26(5): 1805-1830.

Mauss M (1990) The gift: the form and reason for exchange in archaic societies. New York and London: WW Norton.

McGoey L (2012) Philanthrocapitalism and its critics. Poetics 40(2): 185-199.

Monaco S (1992) Orazio e l'epicureismo: alcune osservazioni in margine al problema. (Horace and Epicureanism: some observations) Zetesis 1.

Nisbet R (2007) Horace: life and chronology. In The Cambridge Companion to Horace, 7-21. Cambridge: Cambridge University Press.

Nuzzo G (2006) I quattro libri delle Odi e l'Inno Secolare di Quinto Orazio Flacco. (The four books of Odes and the Carmen Saeculare by Horace). Palermo: Flaccovio Editore.

Oliensis E (1998) Horace and the rhetoric of authority. Cambridge: Cambridge University Press.

Ostrower F (1997) Why the wealthy give: the culture of elite philanthropy. Princeton: Princeton University Press.

Saller R (1982) Personal patronage under the early empire. Cambridge: Cambridge University Press.

White P (2012) Positions for poets in early Imperial Rome. In Literary and Artistic Patronage in Ancient Rome, 50-66. Texas: University of Texas Press.

Williams G (2012) Phases in political patronage of literature in Rome. In Literary and Artistic Patronage in Ancient Rome, 3-27. Texas: University of Texas Press.

Zolotoy L, O'Sullivan D, Klein J (2019) Character cues and contracting costs: the relationship between philanthropy and the cost of capital. Journal of Business Ethics 154(2): 497-515. 